\title{
Development of Micro Hydro Power Plant Prototype as A Field Laboratory for Educational and Research Purposes
}

\author{
Yanuar Z. Arief \\ Dept. of Electrical and Electronic Eng. \\ Faculty of Engineering \\ Universiti Malaysia Sarawak (UNIMAS) \\ Kota Samarahan,, Sarawak, Malaysia \\ ayzulardiansyah@unimas.my
}

\author{
M. F. A. Rahim \\ Institute of High Voltage \& High Current \\ Faculty of Engineering \\ Universiti Teknologi Malaysia (UTM) \\ Johor Bahru, Johor, Malaysia
}

\author{
Naemah Mubarakah \\ Dept. of Electrical Engineering, \\ Faculty of Engineering \\ Universitas Sumatera Utara (USU) \\ Medan, Indonesia \\ naemah@usu.ac.id
}

\author{
Mohd Hafiez Izzwan Saad \\ Dept. of Electrical and Electronic Eng. \\ Faculty of Engineering \\ Universiti Malaysia Sarawak(UNIMAS) \\ Kota Samarahan, Sarawak, Malaysia
}

\author{
Hamzah Eteruddin \\ Department of Electrical Engineering, \\ Faculty of Engineering, \\ Universitas Lancang Kuning (UNILAK), \\ Jl. Yos Sudarso, KM 8 Rumbai, Pekanbaru \\ Riau, Indonesia
}

\begin{abstract}
The need for cheaper electricity generation rises as the price of fossil fuels is increasingly nowadays. Hydropower plant is one of the most efficient and environmentally friendly alternative power plant sources. In this research works, a prototype of small-scale hydro power plant known as micro hydro power plant (MHPP) was developed for educational and research purpose. The motivation of this work is based on there is no field laboratory could be used for students to study the concept and actively involved in electricity generation at Universiti Teknologi Malaysia (UTM) Johor Bahru campus, Malaysia. This work hopefully become the catalyst for further research regarding renewable energy source, particularly in MHPP research. The research flow for this work begins with feasibility activities to determine some potential sites for development of MHPP at UTM Johor Campus. There are 7 (seven) potential sites based on site visits and data analysis. From the data analysis, the most suitable site chosen for MPPP prototype development. The prototype was built based on the improved design. The results show that the constructed prototype is capable for generating electricity. This prototype can be used as a field laboratory and for educational and research purpose.
\end{abstract}

Keywords-micro hydro power plant, water flow, field laboratory, output voltage, output power.

\section{INTRODUCTION}

Micro hydro power plant as one of renewable energy source is a small-scale power plant that uses hydropower as its driving force such as irrigation canals, small rivers or natural waterfalls by utilizing the head and the amount of water discharge. Technically, micro-hydro power plant has three main components, namely water (as an energy source), turbine and generator. This power plant gets energy from the flow of water that has a certain height difference. Basically, it utilizes the potential energy of falling water (head). The higher the water drop, the greater the potential energy of the water that can be converted into electrical energy. In addition to geographical factors (river layout), the height of falling water can also be obtained by stemming the flow of water so that the water level becomes high. It is a system of converting energy from the form of height and flow (potential energy) into the form of mechanical energy and electrical energy. The incoming power (Pin) is the sum of the generated power (Pout) plus the energy loss factor (Ploss) in the form of sound or heat. The power produced is the product of the input power multiplied by the conversion efficiency.

The difference between a normal hydroelectric power plants and a micro-hydro one, especially in the amount of electricity produced, hydropower under the size of $200 \mathrm{~kW}$ is classified as micro-hydro. The relatively small amount of energy produced by micro-hydro compared to large-scale hydropower, has implications for the relatively simple equipment and small area required for micro-hydro installation and operation. This is one of the advantages of micro hydro, which does not cause environmental damage. Thus, the micro-hydropower system is suitable for reaching the availability of electrical energy networks in remote and rural areas that are not able to be reached by the power electricity company like TNB in Malaysia. Moreover, it is necessary for engineering student, particularly electrical engineering student to know the concept and actively involved in development of micro-hydro power plant.

According to TNB, source of hydropower electricity in Malaysia is about $18,500 \mathrm{MW}$ and this represents about $20 \%$ of total power plant in Malaysia [1-2]. For micro-hydro power plant, Malaysia has also great potential due to the hilly topography of many places in this country [3].

Moreover, it is necessary for engineering student, particularly electrical engineering student to know the concept 